Pengaruh Kecerdasan Emosional dan Spiritual terhadap Kinerja Perawat dengan Organizational Citizenship Behaviour sebagai Variabel Intervening

\title{
Pengaruh Kecerdasan Emosional dan Spiritual terhadap Kinerja Perawat dengan Organizational Citizenship Behaviour sebagai Variabel Intervening
}

\author{
Nur Aziza' ${ }^{1}$, Lussia Mariesti Andriany ${ }^{2}$ \\ Institut Teknologi dan Bisnis Asia Malang, Indonesia
}

$\bowtie$ Corresponding Author:

Nama Penulis: Lussia Mariesti Andriany

E-mail: lussiaandriany@asia.ac.id

\begin{abstract}
:
This study aims to determine the influence of emotional Quotient and Spiritual Quotient to the Nurse Performance with Organizational Citizenship Behavior (OCB) as an intervening variable at RSUD Dr. R. Soedarsono Pasuruan.

This study uses path analysis, validity test, reliability test, classic assumption test and hypothesis test. Data collection using observation, interviews, documentation, and questionnaires. Population in this study were all nurse at RSUD Dr. R Soedarsono Pasuruan and the sampling technique that is used is simple random sampling as many as 57 respondents. The result showed that : 1) there is no direct influence of emotional quotient on $O C B$; 2) there is a direct influence of spiritual quotient on OCB; 3) there is a direct influence of emotional quotient on the nurse performance; 4) there is a direct influence of spiritual quotient on the nurse performance; 5) there is no direct influence of $O C B$ on the nurse performance; 6) there is no indirect influence of emotional quotient on the nurse performance through $O C B ; 7)$ there is no indirect influence of spiritual quotient on the nurse performance through $O C B$.
\end{abstract}

Keywords : Emotional Quotient, Spiritual Quotient, Organizational Citizenship Behaviour, Performance

\begin{abstract}
Abstrak:
Penelitian ini bertujuan untuk mengetahui pengaruh variabel kecerdasan emosional dan kecerdasan spiritual terhadap kinerja perawat dengan organiational citizenship behaviour (OCB) sebagai variabel intervening pada RSUD $\operatorname{Dr} R$ Soedarsono Kota Pasuruan.

Penelitian ini menggunakan metode analisis jalur, uji validitas, uji reliabilitas, uji asumsi klasik, dan uji hipotesis. Pengumpulan data dengan menggunakan observasi, wawancara, dokumentasi dan angket. Populasi dalam penelitian ini adalah seluruh perawat di RSUD $\mathrm{Dr} R$ Soedarsono Pasuruan dan teknik sampling yang digunakan adalah, simple random sampling sejumlah 57 responden.Hasil penelitian menunjukkan bahwa : 1) Tidak ada pengaruh langsung kecerdasan emosional terhadap OCB; 2) Ada pengaruh langsung kecerdasan spiritual terhadap organizational citizenship behaviour OCB; 3) Ada pengaruh langsung kecerdasan emosional terhadap kinerja; 4) Ada pengaruh langsung kecerdasan spiritual terhadap kinerja; 5) Tidak ada pengaruh langsung OCB terhadap kinerja; 6) tidak ada pengaruh tidak langsung kecerdasan emosional terhadap kinerja melalui OCB; 7) tidak ada pengaruh tidak langsung kecerdasan spiritual terhadap kinerja melalui $O C B$.

Kata kunci : Kecerdasan Emosional, Kecerdasan Spiritual, Organizational Citizenship Behaviour, Kinerja
\end{abstract}


Pengaruh Kecerdasan Emosional dan Spiritual terhadap Kinerja Perawat dengan Organizational Citizenship Behaviour sebagai Variabel Intervening

\section{PENDAHULUAN}

Sumber daya manusia menempati posisi yang cukup strategis dalam kehidupan suatu organisasi karena berhasil ataupun gagalnya suatu organisasi dalam mencapai tujuannya, pada analisis terakhir akan tetap ditentukan oleh unsur manusia didalamnya. Menurut Mangkunegara (2010) karyawan merupakan sumber daya yang penting bagi perusahaan karena memiliki akal, bakat, tenaga, keinginan, pengetahuan, perasaan, dan kreativitas yang sangat dibutuhkan oleh perusahaan untuk mencapai visi dan misi perusahaan. Pencapaian visi dan misi perusahaan dapat dilakukan melalui penciptaan kinerja perusahaan. Perwujudan dari kinerja perusahaan sangat ditentukan dari kinerja para karyawannya, tinggi rendahnya kinerja perusahaan dipengaruhi oleh kinerja karyawan. Permasalahan terhadap kinerja karyawan merupakan hal yang sangat penting diperhatikan oleh pihak manajemen perusahaan, untuk itu dibutuhkan faktor yang mempengaruhi tinggi dan rendahnya kinerja karyawan.

Menurut Mangkunegara (2010) kinerja adalah hasil kerja secara kualitas dan kuantitas yang dicapai oleh seorang pegawai dalam melaksanakan tugasnya sesuai dengan tanggung jawab yang diberikan kepadanya. Sejalan dengan pernyataan tersebut, Moeheriono (2014) mendefinisikan kinerja sebagai prestasi kerja atau prestasi sesungguhnya yang telah dicapai oleh seorang karyawan dan kinerja karyawan akan baik apabila kualitas kerjanya juga baik.

Untuk mewujudkan itu semua, rumah sakit yang merupakan tempat pelayanan kesehatan harus mampu menyediakan sumber daya yang professional, salah satunya adalah perawat. Tenaga keperawatan merupakan tenaga kesehatan yang secara berkesinambungan memberikan pelayanan keperawatan di rumah sakit secara terus menerus selama 24 jam setiap hari, 365 hari setahun. Oleh karena itu organisasi rumah sakit haruslah mengelola sumber daya manusia dengan baik khususnya SDM keperawatan, karena tenaga keperawatan merupakan jumlah terbesar (50-60 \%) di rumah sakit dan berkontribusi $60 \%$ dari total pelayanan kesehatan yang ada di rumah sakit. 
Pengaruh Kecerdasan Emosional dan Spiritual terhadap Kinerja Perawat dengan Organizational Citizenship Behaviour sebagai Variabel Intervening Untuk menciptakan kinerja yang baik, seorang perawat harus mempunyai kecerdasan emosi agar mampu melaksanakan kontrol personal dengan baik sehingga dapat bekerja secara profesional. Menurut Goleman (2015) kecerdasan emosional adalah kemampuan pengendalian diri, semangat dan ketekunan, serta kemampuan untuk memotivasi diri sendiri. Goleman (2006) melalui penelitiannya menyatakan bahwa kecerdasan emosi menyumbang $80 \%$ dari faktor penentu kesuksesan seseorang, sedangkan 20\% yang lain ditentukan oleh IQ.

Selain kecerdasan emosional, hal lain yang perlu diperhatikan berkaitan dengan kinerja perawat adalah kecerdasan spiritual. Kecerdasan spiritual memungkinkan seseorang untuk berpikir kreatif, berwawasan jauh, membuat atau bahkan mengubah aturan yang membuat orang tersebut dapat bekerja lebih baik. Zohar \& Marshall (2007) mengatakan bahwa kecerdasan spiritual merupakan kecerdasan yang bertumpu pada bagian dalam diri yang berhubungan dengan kearifan di luar ego atau jiwa kesadaran. Sebagai kecerdasan yang senantiasa dipergunakan bukan hanya untuk mengetahui nilai-nilai yang ada, melainkan juga untuk secara kreatif menemukan nilai-nilai baru dalam kehidupan. Seorang perawat yang memiliki kecerdasan spiritual diharapkan mampu menghadapi pasien yang membutuhkan spiritual support, pasien yang ketakutan, cemas, maupun pasien yang harus merubah gaya hidup dengan perlakuan yang tepat.

Dengan kecerdasan emosional dan kecerdasan spiritual yang ada pada diri seseorang maka sikap OCB (organizational citizenship behavior) yang diharapkan dalam suatu perusahaan ataupun organisasi sangat mungkin untuk diwujudkan. Individu (karyawan) akan dengan mudah memunculkan emosi positif untuk mencapai tujuan, meningkatkan kreativitas dan keterampilan dalam mengambil keputusan serta dapat mengubah penderitaan menjadi semangat (motivasi). Organizational Citizenship Behavior (OCB) adalah perilaku individu yang ekstra, yang tidak secara langsung atau eksplisit dapat dikenali dalam suatu sistem kerja yang formal, dan yang secara agregat mampu meningkatkan efektivitas fungsi organisasi (Organ et al., 2006). 
Pengaruh Kecerdasan Emosional dan Spiritual terhadap Kinerja Perawat dengan Organizational Citizenship Behaviour sebagai Variabel Intervening Hasil penelitian terdahulu memberikan bukti bahwa kecerdasan emosional dan kecerdasan spiritual berpengaruh positif dan signifikan terhadap kinerja pegawai, seperti yang ditunjukkan pada penelitian yang dilakukan oleh Meidah (2013). Sejalan dengan hasil tersebut Tribuwono (2015) menyatakan kecerdasan emosional dan kecerdasan spiritual berpengaruh positif dan signifikan terhadap kinerja karyawan. Berbeda dengan hasil sebelumnya, penelitian Satrigaha (2016) dan Rosdaranita (2017) menyatakan bahwa kecerdasan emosional dan kecerdasan spiritual tidak berpengaruh terhadap kinerja karyawan. Penelitian lain juga dilakukan oleh Kaori (2015) yang menunjukkan bahwa ada pengaruh kecerdasan emosional terhadap kinerja pelayanan melalui OCB dan ada pengaruh kecerdasan spiritual terhadap kinerja pelayanan melalui OCB.

Berdasarkan penjabaran di atas, maka penelitian ini bertujuan untuk mengkaji kembali hubungan antara kecerdasan emosional dan kecerdasan spiritual terhadap kinerja dengan organizational citizenship behavior (OCB) sebagai variabel intervening dengan obyek yang berbeda. Artikel ini terbagi menjadi beberapa bagian, yaitu pendahuluan, metode penelitian, hasil penelitian, pembahasan, dan kesimpulan.

\section{METODE PENELITIAN}

\section{a. Objek Penelitian}

Penelitian ini mengambil objek penelitian pada RSUD Dr. R Soeadarsono Pasuruan yang beralamat di Jl. Dokter Wahidin Sudiro Husodo No 1-4, Pututrejo, Purworejo, Kota Pasuruan (67117).

\section{b. Populasi dan Sampel}

Populasi yang digunakan adalah keseluruhan perawat di RSUD Dr R. Soedarsono Kota Pasuruan yang berjumlah 130 orang. Teknik pengambilan sampel pada penelitian ini menggunakan simple random sampling. Ukuran sampel dihitung berdasarkan rumus Slovin dan didapat sampel sejumlah 57 responden yaitu perawat di RSUD Dr. R. Soedarsono. 
Pengaruh Kecerdasan Emosional dan Spiritual terhadap Kinerja Perawat dengan Organizational Citizenship Behaviour sebagai Variabel Intervening c. Kerangka Konseptual dan Hipotesis

Kerangka konseptual pada penelitian ini tergambar pada Gambar 1.



Gambar 1. Kerangka Konseptual Penelitian

Berdasarkan kerangka konseptual tersebut, maka hipotesis pada penelitian ini adalah sebagai berikut:

H1 : diduga ada pengaruh langsung variabel kecerdasan emosional (X1) terhadap organizational citizenship behavior (OCB) (Z) perawat di RSUD Dr R. Soedarsono Kota Pasuruan.

H2 : diduga ada pengaruh langsung variabel kecerdasan spiritual (X2) terhadap organizational citizenship behavior (OCB) (Z) perawat di RSUD Dr R. Soedarsono Kota Pasuruan.

H3 : diduga ada pengaruh langsung variabel kecerdasan emosional (X1) terhadap kinerja perawat (Y) di RSUD Dr R. Soedarsono Kota Pasuruan.

H4 : diduga ada pengaruh langsung variabel kecerdasan spiritual (X2) terhadap kinerja perawat (Y) di RSUD Dr R. Soedarsono Kota Pasuruan.

H5 : diduga ada pengaruh langsung variabel organizational citizenship behavior (OCB) (Z) terhadap kinerja perawat (Y) di RSUD Dr R. Soedarsono Kota Pasuruan.

H6 : diduga ada pengaruh tidak langsung variabel kecerdasan emosional 
Pengaruh Kecerdasan Emosional dan Spiritual terhadap Kinerja Perawat dengan Organizational Citizenship Behaviour sebagai Variabel Intervening (X1) terhadap kinerja perawat (Y) dengan organizational citizenship behavior (OCB) (Z) sebagai variabel intervening pada RSUD Dr R. Soedarsono Kota Pasuruan.

H7 : diduga ada pengaruh tidak langsung variabel kecerdasan Spiritual (X2) terhadap kinerja perawat $(\mathrm{Y})$ dengan organizational citizenship behavior (OCB) (Z) sebagai variabel intervening pada RSUD Dr R. Soedarsono Kota Pasuruan.

\section{Definisi Operasional Variabel}

\section{Kecerdasan Emosional (X1)}

Kecerdasan emosional adalah kemampuan pengendalian diri, semangat dan ketekunan, serta kemampuan untuk memotivasi diri sendiri yang dimiliki perawat di RSUD Dr R Soedarsono Kota Pasuruan. Dalam penelitian ini, variabel Kecerdasan Emosional menggunakan 5 indikator yaitu: kesadaran diri, pengendalian diri, motivasi, empati dan keterampilan sosial.

\section{Kecerdasan Spiritual (X2)}

Kecerdasan spiritual diartikan sebagai kecerdasan yang bertumpu pada bagian dalam diri yang berhubungan dengan kearifan di luar ego atau jiwa kesadaran sebagai kecerdasan yang senantiasa dipergunakan bukan hanya untuk mengetahui nilai-nilai yang ada, melainkan juga untuk secara kreatif menemukan nilai-nilai baru dalam kehidupan yang dimiliki perawat di RSUD Dr R. Soedarsono Kota Pasuruan. Variabel Kecerdasan spiritual pada penelitian ini menggunakan 5 indikator yaitu: mutlak jujur, keterbukaan, pengetahuan diri, fokus pada kontribusi dan spiritual non dogmatis.

\section{Organizational Citizenship Behaviour (Z)}

Organizational Citizenship Behavior (OCB) merupakan perilaku yang ekstra, yang tidak secara langsung atau eksplisit dapat dikenali dalam suatu sistem kerja yang formal, dan yang secara agregat mampu meningkatkan efektivitas fungsi organisasi yang dimiliki oleh perawat di RSUD Dr. R Soedarsono Pasuruan. Variabel Organizational Citizenship Behavior (OCB) pada penelitian ini menggunakan lima (5) indikator yaitu : Altruism (perilaku membantu orang lain), Courtesy (menjaga hubungan baik), Civic Virtue (kebijaksanaan warga), 
Pengaruh Kecerdasan Emosional dan Spiritual terhadap Kinerja Perawat

dengan Organizational Citizenship Behaviour sebagai Variabel Intervening Conscientousness (ketelitian dan kehatihatian), dan Sportmanship (perilaku yang sportif).

\section{Kinerja (Y)}

Kinerja (prestasi kerja) adalah hasil kerja secara kualitas dan kuantitas yang dicapai oleh perawat di RSUD Dr R Soedarsono Pasuruan dalam melaksanakan tugasnya sesuai dengan tanggung jawab yang diberikan. Variabel Kinerja dalam penelitian ini akan dikaji dengan menggunakan 5 indikator yaitu kualitas, kuantitas, ketepatan waktu, efektifitas, kemandirian, komitmen.

\section{E. Teknik Pengumpulan dan Analisis Data}

Data dikumpulkan dengan cara survei langsung menggunakan angket berskala Likert 1-5. Instrumen penelitian telah diuji validitas dan reliabilitasnya. Tahapan analisis data yang dilakukan pada penelitian ini adalah sebagai berikut:

1. Uji asumsi klasik (uji normalitas, uji multikolinieritas, dan uji heteroskedastisitas)

2. Analisis jalur

3. Uji sobel

\section{HASIL PENELITIAN}

\section{a. Hasil Uji Asumsi Klasik}

Berikut disajikan hasil dari masing-masing uji asumsi klasik.

Tabel 1. Hasil Uji Asumsi Klasik

\begin{tabular}{lll}
\hline Uji Asumsi Klasik & \multicolumn{2}{c}{ Keputusan } \\
\hline 1. Uji Normalitas & Gambar $\quad$ menunjukkan \\
& bahwa titik-titik sebaran \\
& data berada disekitar garis \\
& regresi. & Hal ini \\
& menunjukkan bahwa data \\
& terdistribusi normal.
\end{tabular}


Pengaruh Kecerdasan Emosional dan Spiritual terhadap Kinerja Perawat dengan Organizational Citizenship Behaviour sebagai Variabel Intervening Normal P-P Plot of Regression Standardized Residual



2. Uji Multikolinieritas

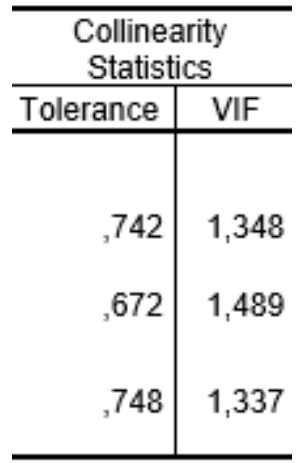

Diketahui nilai VIF dari

kedua variabel tersebut

lebih kecil dari 10, sehingga

dapat disimpulkan bahwa

data tersebut tidak terjadi

multikolinearitas.

3. Uji Heteroskedastisitas

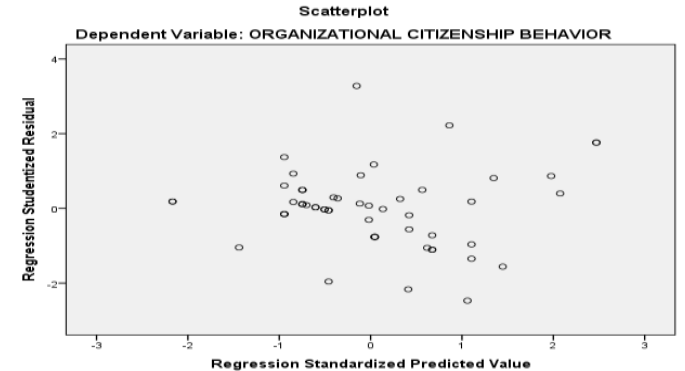

Berdasarkan scatterplot

dapat dilihat bahwa data

tersebut menyebar dan

tidak membentuk pola

tertentu sehingga tidak

terjadi heteroskedastisitas.

Sumber: data diolah (2020)

\section{b. Hasil Analisis Jalur}

Analisis jalur dilakukan sesuai dengan model substruktural yang telah ditentukan yaitu :

$$
\begin{array}{ll}
Z=\beta Z X_{1}+\beta Z X_{2}+\varepsilon 1 & \text { (Substruktural 1) } \\
Y=\beta Y X^{1}+\beta Y X^{2}+\beta Z Y+\varepsilon 2 & \text { (Substruktural 2) }
\end{array}
$$


Pengaruh Kecerdasan Emosional dan Spiritual terhadap Kinerja Perawat dengan Organizational Citizenship Behaviour sebagai Variabel Intervening 1) Pengujian substruktural 1

Pada Tabel 2 di bawah ini disajikan hasil analisis regresi untuk substruktural 1.

Tabel 2. Hasil Analisis Regresi Substruktural 1

\begin{tabular}{|l|c|c|c|}
\hline \multicolumn{1}{|c|}{ Variabel Bebas } & $\begin{array}{c}\text { Standardized } \\
\text { Coefficient Beta }\end{array}$ & $\mathrm{t}$ & Sig. \\
\hline Constanta & - & 3,744 &, 000 \\
\hline Kecerdasan Emosional & 0,196 & 1,460 &, 150 \\
\hline Kecerdasan Spiritual & 0,378 & 2,824 &, 007 \\
\hline Variabel Terikat $=$ Organizational Citizenship Behavior (OCB) & \\
$\mathrm{R} \quad=0,502$ & \\
$\mathrm{R}$ Square $\left(\mathrm{R}^{2}\right)$ & $=0,252$ & & \\
Se & $=2,67182$ & & \\
\hline
\end{tabular}

Sumber: data diolah (2020)

Berdasarkan nilai signifikansi (Sig.) pada Tabel 2, maka dapat diambil kesimpulan sebagai berikut:

a. H1: ada pengaruh langsung variabel kecerdasan emosional terhadap organizational citizenship behavior (OCB) ditolak karena nilai Sig. lebih dari 0.05 .

b. H2: ada pengaruh langsung variabel kecerdasan spiritual terhadap organizational citizenship behavior (OCB) diterima karena nilai Sig. kurang dari 0.05 .

\section{2) Pengujian substruktural 2}

Pada Tabel 3 di bawah ini disajikan hasil analisis regresi untuk substruktural 2.

Tabel 3. Hasil Analisis Regresi Substruktural 2

\begin{tabular}{|c|c|c|c|}
\hline Variabel Bebas & $\begin{array}{c}\text { Standardized } \\
\text { Coefficient Beta }\end{array}$ & $\mathbf{t}$ & Sign \\
\hline Constanta & - & 1,826 & 073 \\
\hline Kecerdasan Emosional & 0,327 & 2,654 &, 010 \\
\hline Kecerdasan Spiritual & 0,397 & 3,068 & ,003 \\
\hline $\begin{array}{l}\text { Organizational Citizenship } \\
\text { Behavior (OCB) }\end{array}$ & 0,020 & , 166 & ,869 \\
\hline $\begin{array}{ll}\text { Variabel Terikat } & =\text { Kinerja } \\
\mathrm{R} & =0,634 \\
\mathrm{R} \text { Square }\left(\mathrm{R}^{2}\right) & =0,402 \\
\mathrm{Se} & =3,23945\end{array}$ & & & \\
\hline
\end{tabular}

Sumber: data diolah (2020) 
Pengaruh Kecerdasan Emosional dan Spiritual terhadap Kinerja Perawat dengan Organizational Citizenship Behaviour sebagai Variabel Intervening Berdasarkan nilai signifikansi (Sig.) pada Tabel 3, maka dapat diambil kesimpulan sebagai berikut:

a. H3: ada pengaruh langsung variabel kecerdasan emosional terhadap kinerja perawat diterima karena nilai Sig. kurang dari 0.05 .

b. H4: ada pengaruh langsung variabel kecerdasan spiritual terhadap kinerja karena nilai Sig. kurang dari 0.05.

c. H5: ada pengaruh langsung variabel organizational citizhenship behavior (OCB) terhadap kinerja ditolak karena nilai Sig. lebih dari 0.05.

\section{3) Analisis Jalur (Path Analysis)}

Pada Tabel 4 di bawah ini disajikan total besarnya pengaruh langsung dan tidak langsung.

Tabel 4. Total besarnya pengaruh langsung, dan tidak langsung

\begin{tabular}{|c|c|c|c|c|}
\hline H & $\begin{array}{c}\text { Pengaruh } \\
\text { variabel }\end{array}$ & Langsung & Tidak langsung & Total \\
\hline H1 & X1- Z & 0,196 & - & - \\
\hline H2 & X2 - Z & 0,378 & - & - \\
\hline H3 & Z - Y & 0,020 & - & - \\
\hline H4 & X1 - Y & 0,327 & - & - \\
\hline H5 & X2 - Y & 0,397 & $0,196^{*} 0,020=0,00396$ & 0,334456 \\
\hline H6 & $\mathrm{X} 1-\mathrm{Z}-\mathrm{Y}$ & & $0,378^{*} 0,020=0,00756$ & 0,40456 \\
\hline H7 & $\mathrm{X} 2-\mathrm{Z}-\mathrm{Y}$ & & - & - \\
\hline
\end{tabular}

Sumber: data diolah (2020)

Hasil pengujian diatas membuktikan bahwa kecerdasan emosional (X1) berpengaruh langsung terhadap kinerja perawat $(\mathrm{Y})$, tetapi tidak berpengaruh secara tidak langsung terhadap kinerja perawat melalui organizational citizenship behavior (OCB) (Z). Sejalan dengan hasil tersebut, diketahui bahwa kecerdasan spiritual (X2) berpengaruh langsung terhadap kinerja perawat (Y), tetapi tidak berpengaruh secara tidak langsung terhadap kinerja perawat melalui organizational citizenship behavior (OCB) (Z).

Dari penjelasan diatas, maka H6 dan H7 ditolak dengan asumsi bahwa kecerdasan emosional dan spiritual tidak berpengaruh terhadap kinerja 
Pengaruh Kecerdasan Emosional dan Spiritual terhadap Kinerja Perawat dengan Organizational Citizenship Behaviour sebagai Variabel Intervening perawat melalui organizational citizenship behavior (OCB).

Pada Gambar 2 di bawah ini digambarkan diagram jalur setelah dilakukan analisis data.



\section{Gambar 2. Diagram Jalur}

\section{c. Hasil Uji Sobel}

Untuk mengetahui pengaruh mediasi yang ditunjukkan oleh perkalian $\left(\mathrm{P}_{1} \mathrm{xP}_{3}\right)=0,00396$ signifikan atau tidak, diuji dengan sobel test. Berdasarkan hasil uji sobel test diketahui nilai Sobel Test Statistic variabel X1 terhadap variabel Y melalui Z sebesar 0,16332491 < nilai Z Score $\alpha=0,05(1,96)$. Dan nilai Sobel Test Statistic variabel X2 terhadap variabel Y melalui Z sebesar $0,16342897<$ nilai Z Score $\alpha=0,05(1,96)$ Hal ini menunjukkan bahwa organizational citizenship behavior (OCB) tidak dapat menjelaskan hubungan tidak langsung antara kecerdasan emosional dan kinerja serta kecerdasan spiritual dan kinerja.

\section{PEMBAHASAN}

\section{A. Pengaruh langsung kecerdasan emosional terhadap kinerja organizational citizenship behavior (OCB)}

Pada RSUD Dr R Soedarsono Kota Pasuruan, kecerdasan emosional tidak dapat mendorong perawat untuk memiliki sikap organizational citizenship behavior dalam menghadapi pasien, maupun rekan kerja saat melaksakan tugas 
Pengaruh Kecerdasan Emosional dan Spiritual terhadap Kinerja Perawat

dengan Organizational Citizenship Behaviour sebagai Variabel Intervening sehari-hari. Perawat yang mampu mengendalikan dan mengelola emosi belum tentu dapat menciptakan sikap OCB. Hal ini disimpulkan berdasarkan kuesioner yang disebarkan, masih terdapat perawat yang menghabiskan waktu untuk pembicaraan diluar pekerjaan. Mereka beranggapan bahwa ada kalanya perawat bercengkrama satu sama lain untuk menjalin hubungan baik antar rekan kerja. Jadi meskipun mereka mampu mengelola emosi dengan baik, namun belum tentu memiliki sikap OCB. Penelitian ini bertentangan dengan penelitian yang dilakukan oleh Kaori (2015) yang menjelaskan bahwa kecerdasan emosional secara positif dan signifikan berpengaruh terhadap organizational citizenship behavior (OCB) pada karyawan PT PLN (Persero) Area Jember.

\section{B. Pengaruh langsung kecerdasan spiritual terhadap organizational citizenship behavior (OCB)}

Kecerdasan spiritual yang dimiliki oleh seorang perawat maka akan mendorong terbentuknya perilaku ekstra (OCB) dalam melaksanakan tugas dan kewajiban pekerjaan sehari-hari. Saat ini kegiatan spiritualitas yang diadakan oleh RSUD Dr R Soedarsono Kota Pasuruan adalah kegiatan pengajian di setiap hari rabu setelah sholat dhuhur yang berlokasi di Masjid AS-Syifa di RSUD Dr R Soedarsono Kota Pasuruan. Selain itu pihak Pemkot Pasuruan juga mengalokasikan dana untuk kegiatan pengajian ini dengan mengundang tokoh agama. Dengan adanya kegiatan pengajian rutin tersebut mampu menciptakan sikap OCB dari perawat di RSUD Dr R Soedarsono Kota Pasuruan dalam menghadapi pasien maupun rekan kerja. Hal ini didukung oleh penelitian yang dilakukan oleh Kaori (2015) yang menjelaskan bahwa kecerdasan spiritual secara positif dan signifikan berpengaruh terhadap organizational citizenship behavior (OCB) pada karyawan PT PLN (Persero) Area Jember.

\section{Pengaruh langsung kecerdasan emosional terhadap kinerja}

Kecerdasan emosional mampu meningkatkan kinerja perawat. Perawat yang mampu mengelola emosi dengan baik saat berhadapan langsung dengan pasien maupun keluarga pasien serta rekan kerja akan mampu mekasanakan pekerjaan dengan baik dan maksimal. Saat ini, di RSUD Dr R Soedarsono Kota 
Pengaruh Kecerdasan Emosional dan Spiritual terhadap Kinerja Perawat

dengan Organizational Citizenship Behaviour sebagai Variabel Intervening Pasuruan telah menerapkan nilai-nilai perusahaan untuk meningkatkan kinerja.

Salah satunya yaitu "selalu mengutamakan penderita dengan penuh kerendahan hati dan selalu bersedia untuk menolong". Dan untuk mewujudkan itu semua maka perawat harus memiliki kecerdasan emosional, sehingga mampu melaksanakan pekerjaan dengan baik dan maksimal. Perwujudan kecerdasan emosional salah satunya adalah bagaimana mengendalikan emosi ketika berhadapan dengan pasien atau keluarga pasien. Hal tersebut akan berdampak pada kenyamanan dan kepuasan pasien yang tentunya akan menjadi poin penting untuk menilai kinerja perawat.

Hal ini didukung oleh penelitian Rosdaranita (2017) yang menyatakan bahwa kecerdasan emosional mempunyai pengaruh yang positif dan signifikan terhadap kinerja karyawan di CV. Sidiq Manajemen Yogyakarta. Selain itu, hasil penelitian juga sejalan dengan penelitian Jamal (2016) yang menyatakan bahwa kecerdasan emosional berpengaruh positif dan signifikan terhadap kinerja karyawan Lembaga ESQ Leardership Center Jakarta.

\section{Pengaruh langsung kecerdasan spiritual terhadap kinerja}

Kecerdasan spiritual yang dimiliki oleh perawat sangat penting dalam meningkatkan kinerja perawat di RSUD Dr R Sodarsono Kota Pasuruan. Hasil penelitian ini mendukung asumsi penelitian dari Oxford University yang menyatakan bahwa spiritualitas berkembang karena manusia krisis makna, jadi kehadiran organisasi seharusnya juga member makna apa yang menjadi tujuan organisasinya. Makna yang muncul dalam suatu organisasi akan membuat setiap orang yang bekerja didalamnya lebih dapat mengembangkan diri mereka dan dapat bekerja lebih baik Jamal (2016). Penelitian ini juga sejalan dengan hasil penelitian tersebut yaitu pengaruh kecerdasan spiritual dalam dunia kerja yang menunjukkan bahwa kecerdasan spiritual mempengaruhi tujuan seseorang dalam mencapai karirnya di dunia kerja. Seseorang yang membawa makna spiritualitas dalam kerjanya akan merasakan hidup dan pekerjaannya lebih berarti. Hal ini mendorong dirinya untuk lebih meningkatkan kinerja yang dimiliki. 
Pengaruh Kecerdasan Emosional dan Spiritual terhadap Kinerja Perawat dengan Organizational Citizenship Behaviour sebagai Variabel Intervening

\section{E. Pengaruh langsung Organizational Citizenship Behavior (OCB) terhadap kinerja}

Organizational Citizenship Behavior (OCB) yang dimiliki perawat di RSUD Dr R Soedarsono Kota Pasuruan tidak berpengaruh signifikan terhadap peningkatan kinerja perawat. Berdasarkan hasil wawancara yang dilakukan oleh peneliti kepada kepala bidang keperawatan RSUD Dr R Soedarsono Kota Pasuruan, organizational citizenship behavior (OCB) juga dibutuhkan dalam upaya untuk meningkatkan kinerja perawat. hal ini karena OCB merupakan salah satu perilaku yang yang harus dimiliki oleh perawat dalam bekerja. Namun setelah mengolah data yang diperoleh dari hasil penyebaran kuesioner, terdapat perbedaan hasil. bahwa OCB justru tidak berpengaruh signifikan terhadap kinerja. Penelitian ini bertentangan dengan penelitian yang dilakukan oleh Kaori (2015) yang menjelaskan bahwa organizational citizenship behavior secara positif dan signifikan berpengaruh terhadap kinerja pada karyawan PT PLN (Persero) Area Jember.

\section{F. Pengaruh tidak langsung kecerdasan emosional terhadap kinerja melalui organizational citizenship behavior (OCB)}

Berdasarkan hasil uji sobel, dapat diketahui bahwa kecerdasan emosional tidak berperan secara tidak langsung terhadap kinerja perawat melalui organizational citizenship behavior (OCB). Artinya, variabel kecerdasan emosional dapat meningkatkan kinerja perawat tanpa melalui organizational citizenship behavior (OCB). Tidak adanya pengaruh mediasi dalam penelitian ini disebabkan karena variabel organizational citizenship behavior (OCB) itu sendiri, dimana OCB tidak menjadi bahan pertimbangan atas variabel kecerdasan emosional dalam meningkatkan kinerja perawat.

Berdasarkan survey yang dilakukan oleh peneliti pada RSUD Dr R Soedarsono Kota Pasuruan menunjukkan bahwa perawat yang memiliki sikap OCB belum tentu memiliki kecerdasan emosional yang baik dalam mengontrol emosinya dan meningkatkan kinerjanya. Jadi, tidak adanya pengaruh mediasi dalam penelitian ini disebabkan karena variabel organizational citizenship behavior (OCB) itu sendiri, dimana OCB tidak menjadi bahan pertimbangan atas 
Pengaruh Kecerdasan Emosional dan Spiritual terhadap Kinerja Perawat

dengan Organizational Citizenship Behaviour sebagai Variabel Intervening variabel kecerdasan emosional dalam meningkatkan kinerja perawat. Penelitian ini bertentangan dengan penelitian yang dilakukan oleh Kaori (2015) yang menjelaskan bahwa ada pengaruh kecerdasan emosional terhadap kinerja karyawan melalui organizational citizenship behavior pada karyawan PT PLN (Persero) Area Jember.

\section{G. Pengaruh tidak langsung kecerdasan spiritual terhadap kinerja melalui organizational citizenship behavior (OCB)}

Berdasarkan hasil uji sobel, dapat diketahui bahwa kecerdasan spiritual tidak berperan secara tidak langsung terhadap kinerja perawat melalui organizational citizenship behavior (OCB). Artinya, variabel kecerdasan spiritual dapat meningkatkan kinerja perawat tanpa melalui organizational citizenship behavior (OCB). Tidak adanya pengaruh mediasi dalam penelitian ini disebabkan karena variabel organizational citizenship behavior (OCB) itu sendiri, dimana OCB tidak menjadi bahan pertimbangan atas variabel kecerdasan spiritual dalam meningkatkan kinerja perawat.

Pada RSUD Dr R Soedarsono Kota Pasuruan, kecerdasan spiritual yang dimiliki oleh perawat telah mampu meningkatkan kinerja perawat. Hal ini terbukti dari dampak diadakannya kegiatan spirtualitas (pengajian rutin) mampu memberikan dampak yang baik dalam peningkatan kinerja karyawan dan dampaknya lebih besar daripada perawat yang yang memiliki sikap OCB dalam meningkatkan kinerja. Penelitian ini bertentangan dengan penelitian yang dilakukan oleh Kaori (2015) yang menjelaskan bahwa ada pengaruh kecerdasan spiritual terhadap kinerja karyawan melalui organizational citizenship behavior pada karyawan PT PLN (Persero) Area Jember.

\section{KESIMPULAN}

Kesimpulan dari penelitian ini adalah:

1. Kecerdasan emosional tidak berpengaruh secara langsung terhadap organizational citizenship behavior (OCB).

2. Kecerdasan spiritual berpengaruh secara langsung terhadap organizational citizenship behavior (OCB). 
Pengaruh Kecerdasan Emosional dan Spiritual terhadap Kinerja Perawat dengan Organizational Citizenship Behaviour sebagai Variabel Intervening

3. Kecerdasan Emosional berpengaruh secara langsung terhadap kinerja perawat.

4. Kecerdasan Spiritual berpengaruh secara langsung terhadap kinerja perawat.

5. Organizational Citizenship Behavior (OCB) tidak berpengaruh secara langsung terhadap kinerj perawat.

6. Kecerdasan emosional tidak berpengaruh secara tidak langsung terhadap kinerja perawat melalui organizational citizenship behavior (OCB).

7. Kecerdasan spiritual tidak berpengaruh secara tidak langsung terhadap kinerja perawat melalui organizational citizenship behavior (OCB).

\section{DAFTAR PUSTAKA}

Goleman, D. (2006). Emotional Intelligence. PT Gramedia Pustaka Utama.

Goleman, D. (2015). Emotional Intelligence (T. Hermaya (ed.); 19th ed.). Gramedia Pustaka Utama.

Jamal, S. F. (2016). Analisis Pengaruh Kecerdasan Emosional dan Kecerdasan Spiritual Terhadap Kinerja Karyawan. Universitas Islam Syarif Hidayatullah.

Kaori, R. M. K. (2015). Pengaruh Kecerdasan Emosional dan Kecerdasan Spiritual Terhadap Kinerja Pelayanan Melalui Organizational Citizenship Behavior (OCB). Universitas Jember.

Mangkunegara, A. P. (2010). Evaluasi Kinerja Sumber Daya Manusia. Remaja Rosdakarya.

Meidah, E. (2013). Pengaruh Konflik Peran Ganda, Kecerdasan Emosional dan Komitmen Organisasi Terhadap Kinerja Perawat Wanita. Universitas Islam Negeri Syarif Hidayatullah.

Moeheriono. (2014). Pengukuran Kinerja Berbasis Kompetensi (Revisi). Raja Grafindo Persada.

Organ, D. W., Podsakof, P. M., \& Mackenzie, S. B. (2006). Organizational Citizenship Behavior: Its Nature Antecedents and Consequences (Second). SAGE Publications, Inc.

Rosdaranita, A. D. (2017). Pengaruh Kecerdasan Spiritual dan Kecerdasan Emosional Terhadap Kinerja Karyawan. Universitas Islam Negeri Sunan Kalijaga.

Satrigaha, N. M. R. P. (2016). Pengaruh Kecerdasan Intelektual, Emosional dan Spiritual Terhadap Kinerja Karyawan. Universitas Udayana.

Tribuwono, C. (2015). Analisis Pengaruh Kecerdasan Emosional (EQ) dan Kecerdasan Spiritual (SQ) pada Kinerja Karyawan.

Zohar, D., \& Marshall, I. (2007). Kecerdasan Spiritual (R. Astuti, A. Nadjib, \& A. Baiquni (eds.)). PT Mizan Pustaka. 